International Journal of Current Advanced Research

ISSN: O: 2319-6475, ISSN: P: 2319 - 6505, Impact Factor: SJIF: 5.995

Available Online at www.journalijcar.org

Volume 6; Issue 3; March 2017; Page No. 2454-2459

DOI: http://dx.doi.org/10.24327/ijcar.2017.2459.0027

Research Article

\title{
BIO-CALCIUM SULFATE PREPARATION FROM DUCK EGGSHELL VIA CHEMICAL REACTION PROCESS
}

\section{Wanitcha Unjan and Nuchnapa Tangboriboon*}

Materials Engineering Department, Faculty of Engineering, Kasetsart University, Bangkok 10900, Thailand

\begin{tabular}{|c|c|}
\hline A $R$ T I C L E I N F O & A B S T R A C T \\
\hline Article History: & \multirow{7}{*}{$\begin{array}{l}\text { Calcium sulfate dihydrate }\left(\mathrm{CaSO}_{4} \cdot 2 \mathrm{H}_{2} \mathrm{O}\right) \text { was prepared from a chemical reaction between } \\
\text { duck eggshell and sulfuric acid at room temperature }\left(25^{\circ} \mathrm{C}\right) \text {. When calcium sulfate } \\
\text { dihydrate is dried in an oven at } 110^{\circ} \mathrm{C} \text {, it can change to calcium sulfate hemihydrate or } \\
\text { plaster of Paris }\left(\mathrm{CaSO}_{4} \cdot 0.5 \mathrm{H}_{2} \mathrm{O}\right) \text {. After that, calcium sulfate hemihydrate }\left(\mathrm{CaSO}_{4} \cdot 0.5 \mathrm{H}_{2} \mathrm{O}\right) \\
\text { was calcined at } 700^{\circ}, 800^{\circ} \text {, and } 900^{\circ} \mathrm{C} \text {, it can transform to anhydrite or anhydrous calcium } \\
\text { sulfate }\left(\mathrm{CaSO}_{4}\right) \text {. Calcium sulfates (calcium sulfate dihydrate }\left(\mathrm{CaSO}_{4} \cdot 2 \mathrm{H}_{2} \mathrm{O}\right) \text {, calcium } \\
\left.\text { sulfate hemihydrate }\left(\mathrm{CaSO}_{4} \cdot 0.5 \mathrm{H}_{2} \mathrm{O}\right) \text {, and anhydrite }\left(\mathrm{CaSO}_{4}\right)\right) \text { can be applied for various } \\
\text { applications i.e. construction, ceramic, petroleum and petrochemical, dental and medical } \\
\text { industries functioning as a filler, binder, coagulant, adsorbent, catalyst, and starting } \\
\text { material such as bone cement, mold making, cement, tissue engineering, etc. Furthermore, } \\
\text { the raw material used in this research is raw duck eggshell which is the waste eggshell } \\
\text { generated from food processing and egg powder industries from the transformation of } \\
\text { liquid to solid powder. The obtained anhydrous calcium sulfate or anhydrite has true } \\
\text { density, color, specific surface area, avg. pore diameter, and avg. particle size equal to } 2.95 \\
\text { g/cm }{ }^{3} \text {, white powder, } 3.57 \mathrm{~m}^{2} / \mathrm{g} \text {, } 96.98 \AA \text { A, and } 3.983 \mu \mathrm{m} \text {, respectively. In addition, } \\
\text { characteristics, microstructures, phase transformation, and physical properties of raw } \\
\text { materials and calcium sulfates are reported here by using XRF, SEM, XRD, pycnometer } \\
\text { method, and BET. }\end{array}$} \\
\hline Received $10^{\text {th }}$ December, 2016 & \\
\hline Received in revised form $7^{\text {th }}$ January, 2017 & \\
\hline Accepted $11^{\text {th }}$ February, 2017 & \\
\hline Published online $28^{\text {th }}$ March, 2017 & \\
\hline Kye Words: & \\
\hline $\begin{array}{l}\text { Calcium sulfate, Duck eggshell, Pyrolysis, } \\
\text { Anhydrite, Construction, Biomaterial. }\end{array}$ & \\
\hline
\end{tabular}

Copyright $\bigcirc 2017$ Wanitcha Unjan and Nuchnapa Tangboriboon. This is an open access article distributed under the Creative Commons

Attribution License, which permits unrestricted use, distribution, and reproduction in any medium, provided the original work is properly cited.

\section{INTRODUCTION}

Calcium sulfate is a ceramic material useful for many kinds of industrial applications i.e. a binder for building material, bone graft materials, periodontal disease treatment, endodontic lesions, alveolar bone loss, maxillary sinus augmentation, filler for plastic, rubber, coating, and construction materials, desiccant, coagulant, and catalysts $[1,2,3]$. In general, calcium sulfate compounds in the form of $\gamma$-or $\beta$-anhydrite (the nearly anhydrous) namely anhydrous calcium sulfate, calcium sulfate hemihydrate or plaster of Paris, and gypsum $\left(\mathrm{CaSO}_{4} \cdot 2 \mathrm{H}_{2} \mathrm{O}\right)$ are the most abundant sulfate mineral in nature [4]. Natural gypsum or calcium sulfate dihydrate is a monoclinic-prismatic mineral with a layered crystal lattice containing the water. When the crystal lattice heated can be converted to the metastable hemihydrate and anhydrite III, which has a similar lattice structure. Anhydrite III can be transformed to anhydrite II with the most densely packed ion lattice and does not react very readily with water at high temperature [5].

\section{*Corresponding author: Wanitcha Unjan}

Materials Engineering Department, Faculty of Engineering, Kasetsart University, Bangkok 10900, Thailand
Therefore, phase transformation, crystal structure, morphology, and growth rate of calcium sulfate depend on temperature, pressure, dissolved electrolytes or organics, and other minerals [4]. There are many types calcium sulfate i.e. calcium sulfate dihydrate or gypsum $\left(\mathrm{CaSO}_{4} \cdot 2 \mathrm{H}_{2} \mathrm{O}\right)$, subhydrate calcium sulfate $\left(\mathrm{CaSO}_{4} \cdot 0.81 \mathrm{H}_{2} \mathrm{O}\right)$, - and $\beta$ hemihydrate calcium sulfate $\left(\mathrm{CaSO}_{4} \cdot 1 / 2 \quad \mathrm{H}_{2} \mathrm{O}\right)$, calcium sulfate anhydrite I, II, and III $\left(\mathrm{CaSO}_{4}\right)$ [6-12]. The synonyms, characteristics (color, odor, and density values), crystal structures, chemical solubility performances, physical-opticalmechanical properties (translucence, refractive index, hardness, etc.) and their applications are some differences. The calcium sulfate compounds can be prepared by a variety of processes, i.e. dissolved in aqueous sulfuric acid, flue gas desulfurization (FGD), reverse micro-emulsion, chemical precipitation, ion exchange, adsorption, reverse osmosis and electro-chemical methods, etc. [13-21].

Eggshell is a calcium source obtained by the consuming and industries such as food, drug, cosmetics, filler in other industries, etc. The by-product eggshell represents about $11 \%$ of the total weight approximately $60 \mathrm{~g}$ of an egg [22-24]. The main composition of eggshells is calcium carbonate $\left(\mathrm{CaCO}_{3}\right)$ known as calcite more than $94 \mathrm{wt} \%$ and the other oxides, including organic compounds $6 \mathrm{wt} \%$ [22-24]. Therefore, the 
eggshell acts as a useful waste in many kinds of applications [22-27].

The objective of this research is that the duck eggshell was used as a raw material to react with sulfuric acid under calcination temperature in order to prepare the calcium sulfate compounds i.e. calcium sulfate dihydrate or gypsum, hemihydrate or plaster of Paris, and anhydrite. The characteristics, micro- structures, phase transformation, and physical properties of samples were reported here by using XRF, SEM, XRD, pycnometer method, and BET.

\section{Experimental}

\section{MATERIALS AND METHODS}

Duck eggshell was collected from the cafeteria at Kasetsart University, Thailand. The duck eggshells were cleaned with tap water, dried in the air for 2 days, and ground with highspeed mill for $120 \mathrm{~min}$. Hydrosulfuric acid $\left(\mathrm{H}_{2} \mathrm{SO}_{4}\right)$ is in high purity with $98 \%$ and was purchased from Arsom Co., Ltd., Thailand. Hydrosulphuric acid is colorless, odorless, melting temperature at $104^{\circ} \mathrm{C}$ and $1.0 \mathrm{~atm}$.

\section{Instruments}

Muffle furnace (Nebertherm, Ceramotherm with thermocouple type $\mathrm{K}, \mathrm{NiCr}-\mathrm{Ni}$ ) was used to calcine the duck eggshells at $900^{\circ} \mathrm{C}$ for $2 \mathrm{hr}$ with a heating rate of $5^{\circ} \mathrm{C} / \mathrm{min}$. The muffle furnace was used to calcine the precipitate calcium sulfate powder prepared from the reaction between duck eggshell and concentrated sulfuric acid at room temperature, and then calcined at firing temperature $700^{\circ}$, $800^{\circ}$, and $900^{\circ} \mathrm{C}$ for $2 \mathrm{hr}$ with a heating rate of $10^{\circ} \mathrm{C} / \mathrm{min}$. The High-speed mill model RM 1105 with speed $500 \mathrm{rpm}$ was supplied by Compound Clay Co., Ltd., Thailand. The rapid mill is a porcelain pot containing the amount of $2 / 3$ porcelain ball mills of the porcelain pot volume. The rapid mill was used for grinding the duck eggshell to be fine powder for the calcium sulfate preparation. X-ray diffraction (XRD) was taken and analyzed using a Bruker AXS analyzer (D8 Discover) with VANTEC-1 Detector. Samples were analyzed using a double-crystal wide-angle goniometry. Scans were measured from $5^{\circ}-80^{\circ} 2 \theta$ at a scan speed of $5^{\circ} 2 \theta / \mathrm{min}$ in $0.05^{\circ}$ or $0.03^{\circ} 2 \theta$ increments using $\mathrm{Cu} K_{\alpha}$ radiation $(\lambda=$ $0.15406 \mathrm{~nm}$ ). Peak positions were consistent with those of the International Center for Diffraction Data Standard (JCPDS) patterns to identify crystalline phases. Scanning Electron Microscope (SEM) was taken and characterized using SEM, JEOL-5200. The samples of raw material and compliant electrode samples were mounted on a stub using carbon paste and were sputter-coated to $\sim 0.1 \mu \mathrm{m}$ of gold to improve conductivity. The acceleration voltages of 11 and $13 \mathrm{kV}$ with magnifications of 1,000 and 5,000 times were used.

Calcium Sulfate Powder Preparation $\left(\mathrm{CaSO}_{4} \cdot \mathbf{2 H}_{2} \mathrm{O}\right.$, $\mathrm{CaSO}_{4} \cdot 0.5 \mathrm{H}_{2} \mathrm{O}$, and $\mathrm{CaSO}_{4}$ )

The duck eggshell that had been ground for 120 min acted as calcium carbonate source $\left(\mathrm{CaCO}_{3}\right)$ reacts to sulfuric acid at room temperature $\left(25^{\circ} \mathrm{C}\right)$ according to the chemical reaction and equations as shown in (1) and (2):

When the chemical reaction between $\mathrm{CaCO}_{3}$ and $\mathrm{H}_{2} \mathrm{SO}_{4}$ occurred completely, the precipitated calcium sulfate or calcium sulfate dihydrate $\left(\mathrm{CaSO}_{4} \cdot 2 \mathrm{H}_{2} \mathrm{O}\right)$ powder was filtered, rinsed with tap water 2-3 times, and dried in the oven at $110^{\circ} \mathrm{C}$ for $24 \mathrm{hr}$. Calcium sulfate dihydrate $\left(\mathrm{CaSO}_{4} \cdot 2 \mathrm{H}_{2} \mathrm{O}\right)$ can transform to calcium sulfate hemihydrate $\left(\mathrm{CaSO}_{4} \cdot 0.5 \mathrm{H}_{2} \mathrm{O}\right)$ according to the equation (3). After that, the dried calcium sulfate hemihydrate powder was calcined at $700^{\circ}, 800^{\circ}$, and $900^{\circ} \mathrm{C}$ for $2 \mathrm{hr}$. Calcium sulfate hemihydrate converted to anhydrite or anhydrous calcium sulfate $\left(\mathrm{CaSO}_{4}\right)$ according to the equation (4). The obtained calcined powder was measured by the physical properties and characterized by SEM, XRD, particle size distribution, BET, and pycnometer measurement.

RESULTS AND DISCUSSION
Characteristics of Raw Material and Calcium Sulfate
Powder

The chemical compositions of duck eggshell and calcined duck eggshell were measured by XRF as data tabulated in Table 1. The main raw duck eggshell composed of calcium carbonate $\left(\mathrm{CaCO}_{3}\right) 98.101 \mathrm{wt} \%$ and other oxide compounds $1.899 \mathrm{wt} \%$. While the calcined duck eggshell composed of calcium oxide $(\mathrm{CaO}) 97.805 \mathrm{wt} \%$ and the other oxide compounds such as $\mathrm{MgO}, \mathrm{Na}_{2} \mathrm{O}, \mathrm{K}_{2} \mathrm{O}, \mathrm{SiO}_{2}$, etc. $2.195 \mathrm{wt} \%$. The raw duck eggshell and calcined duck eggshell can react with sulfuric acid at room temperature $\left(25^{\circ} \mathrm{C}\right)$ according to the equations (1) and (2) to obtain calcium sulfate dihydrate or gypsum. When calcium sulfate dihydrate was heated, it can transform to calcium hemihydrate or plaster of Paris and anhydrite according to equations (3) and (4), respectively.

Table 1 Chemical composition of raw materials measured by XRF

\begin{tabular}{ccccc}
\hline \multicolumn{2}{c}{ Raw duck eggshells } & \multicolumn{2}{c}{ Calcined duck eggshells } \\
\hline Compounds & Weight $(\%)$ & Compounds & $\begin{array}{c}\text { Weight } \\
(\%)\end{array}$ \\
\hline $\mathrm{Na}_{2} \mathrm{O}$ & 0.204 & $\mathrm{Na}_{2} \mathrm{O}$ & 0.161 \\
$\mathrm{MgO}$ & 0.286 & $\mathrm{MgO}^{2}$ & 0.656 \\
$\mathrm{Al}_{2} \mathrm{O}_{3}$ & 0.035 & $\mathrm{SiO}_{2}$ & 0.255 \\
$\mathrm{SiO}_{2}$ & 0.073 & $\mathrm{P}_{2} \mathrm{O}_{5}$ & 0.775 \\
$\mathrm{P}_{2} \mathrm{O}_{5}$ & 0.443 & $\mathrm{SO}_{3}$ & 0.215 \\
$\mathrm{SO}_{3}$ & 0.764 & $\mathrm{Cl}$ & 0.053 \\
$\mathrm{Cl}$ & 0.035 & $\mathrm{~K}_{2} \mathrm{O}$ & 0.059 \\
$\mathrm{~K}_{2} \mathrm{O}$ & 0.038 & $\mathrm{CaO}$ & 97.805 \\
$\mathrm{CaCO}$ & 98.101 & $\mathrm{SrO}$ & 0.019 \\
$\mathrm{CuO}$ & 0.009 & & \\
$\mathrm{SrO}$ & 0.013 & & \\
\hline
\end{tabular}

\section{Physical Properties and Microstructures of Calcium Sulfate Powder}

The physical properties (average particle size, true density, specific surface area, and average pore diameter) of raw duck eggshell and anhydrous calcium sulfate calcined at $800^{\circ}$ and $900^{\circ} \mathrm{C}$ were measured and reported on the data in Table 2. The particle size distribution at $\mathrm{d}_{90}, \mathrm{~d}_{50}, \mathrm{~d}_{10}$, and $\mathrm{d}_{\text {avg }}$ of raw duck eggshell are 90.02, 15.75, 1.55, and $34.35 \mu \mathrm{m}$, respectively. The true density, specific surface area, and average pore diameter of the raw duck eggshell are 2.25 $\mathrm{g} / \mathrm{cm}^{3}, 7.79 \mathrm{~m}^{2} / \mathrm{g}$, and $196.90 \AA$, respectively. While the particle size distribution at $\mathrm{d}_{90}, \mathrm{~d}_{50}, \mathrm{~d}_{10}$, and $\mathrm{d}_{\text {avg }}$ of the raw duck eggshell reacted to sulfuric acid and calcined at $900^{\circ} \mathrm{C}$ for $2 \mathrm{hr}$ are equal to $7.39,3.13,1.08$, and $3.99 \mu \mathrm{m}$, 
respectively. Furthermore, the true density, specific surface area, and average pore diameter of the raw duck eggshell reacted to sulfuric acid and calcined at $900^{\circ} \mathrm{C}$ for $2 \mathrm{hr}$ for $2 \mathrm{hr}$ are $2.95 \mathrm{~g} / \mathrm{cm}^{3}, 3.57 \mathrm{~m}^{2} / \mathrm{g}$, and $96.98 \AA$, respectively. The porosity of the anhydrous calcium sulfate calcined at $900^{\circ} \mathrm{C}$ for $2 \mathrm{hr}$ is in the range of mesoporous structure $(20 \AA-500 \AA)$. The adsorption-desorption isotherm of anhydrous calcium sulfate or anhydrite is consistent and according to the Kelvin equation having the hysteresis loop at a lower relative pressure, causing a lower free energy state and the thermodynamic equilibrium. The physical properties of the raw duck eggshell and calcium sulfate samples, i.e. particle size and shape, specific surface area, true density, solubility, etc., are important factors for calcium sulfate formation and applications $[6,29,30]$.

Table 2 Physical properties of samples

\begin{tabular}{|c|c|c|c|c|}
\hline Samples & $\begin{array}{l}\text { Avg. particle } \\
\text { size }(\mu \mathrm{m})\end{array}$ & $\begin{array}{c}\text { True } \\
\text { density } \\
\left(\mathrm{g} / \mathrm{cm}^{3}\right)\end{array}$ & $\begin{array}{c}\text { Specific } \\
\text { surface } \\
\text { area } \\
\left(\mathbf{m}^{2} / \mathbf{g}\right) \\
\end{array}$ & $\begin{array}{c}\text { Avg. pore } \\
\text { diameter } \\
(\AA)\end{array}$ \\
\hline Raw duck eggshell & 34.35 & 2.25 & 7.79 & 196.90 \\
\hline $\begin{array}{c}\mathrm{CaSO}_{4} \text { calcined at } \\
800^{\circ} \mathrm{C}\end{array}$ & 5.560 & 2.87 & N/A & N/A \\
\hline $\begin{array}{c}\mathrm{CaSO}_{4} \text { calcined at } \\
900^{\circ} \mathrm{C}\end{array}$ & 3.983 & 2.95 & 3.57 & 96.98 \\
\hline
\end{tabular}

The XRD peak patterns of the raw duck eggshell before and after firing at $900^{\circ} \mathrm{C}$ for $2 \mathrm{hr}$, and the dried calcium sulfate powder obtained from the raw duck eggshell react with sulfuric acid calcined at $700^{\circ}, 800^{\circ}$, and $900^{\circ} \mathrm{C}$, for $2 \mathrm{hr}$, as shown in Fig. 1. The XRD peak pattern of the raw duck eggshell shows the crystalline phase formation of rhombohedral or calcite consistent with the JCPDS file no. 01-086-2339 at the (hkl): (104) $29.364^{\circ},(012) 23.058^{\circ}$, and (113) $39.424^{\circ}$ while the XRD peak pattern of the calcined raw duck eggshell shows the crystalline phase formation of lime or calcia being consistent with the JCPDS file no. 00-0371497 at the (hkl): (200) $37.347^{\circ}$, (220) $53.856^{\circ}$, and (111) $32.204^{\circ}$. The main XRD peak pattern of the dried precipitated calcium sulfate powder before firing shows the rhombohedral structure of calcium sulfate hemihydrate $\left(\mathrm{CaSO}_{4} \cdot 0.5 \mathrm{H}_{2} \mathrm{O}\right)$ consistent with JCPDS file no. 01-070-0909 at the (hkl): (020) $25.432^{\circ}$, (104) $29.364^{\circ}$, (012) $31.366^{\circ},(022) 38.648^{\circ},(212)$ $40.820^{\circ}$, and $(032) 48.696^{\circ}$. Then, the dried precipitated samples, calcium sulfate hemihydrate $\left(\mathrm{CaSO}_{4} \cdot 0.5 \mathrm{H}_{2} \mathrm{O}\right)$ powder calcined at $700^{\circ}$ and $800^{\circ} \mathrm{C}$ for $2 \mathrm{hr}$, show the same XRD peak patterns of the metastable phase of anhydrous calcium sulfate $\left(\mathrm{CaSO}_{4}\right)$ in hexagonal phase formation consistent with the JCPDS file nos. 01-089-1458 and 01-0700909 at the (hkl): (100) $14.665^{\circ},(200) 29.577^{\circ},(102) 32.011^{\circ}$ and (020) $25.432^{\circ},(012) 31.366^{\circ}$, and (212) $40.820^{\circ}$, respectively, mixed with a small amount of the calcium hydroxide or portlandite $\left(\mathrm{Ca}(\mathrm{OH})_{2}\right)$ belong belonging to orthorhombic consistent with the JCPDS file no. 00-004-0733 at the (hkl): (101) $34.089^{\circ}$, (102) $47.124^{\circ}$, and (110) $50.795^{\circ}$. Furthermore, the dried precipitated calcium sulfate dihydrate sample calcined at $900^{\circ} \mathrm{C}$ for $2 \mathrm{hr}$, shows the stable crystalline phase formation of hexagonal namely anhydrite structure $\left(\mathrm{CaSO}_{4}\right)$ consistent with the JCPDS file no.01-089-1458 at the (hkl): (020) $25.432^{\circ},(012) 31.366^{\circ}$, and (022) $38.648^{\circ}$, respectively, consistent with the anhydrite crystal structure obtained by Zhao, Wu et al [3]. Therefore, the obtained XRD phase transformation of calcium sulfate dihydrate $\left(\mathrm{CaSO}_{4} \cdot 2 \mathrm{H}_{2} \mathrm{O}\right)$ can transform to calcium sulfate hemihydrate or plaster of Paris $\left(\mathrm{CaSO}_{4} \cdot 0.5 \mathrm{H}_{2} \mathrm{O}\right)$ or anhydrite $\left(\mathrm{CaSO}_{4}\right)$ crystal structures depending on the firing temperature and firing time consistent with the dehydration-rehydration of calcium sulfates flowchart reported by Singh, N.B. and Middendorf, B. [31].

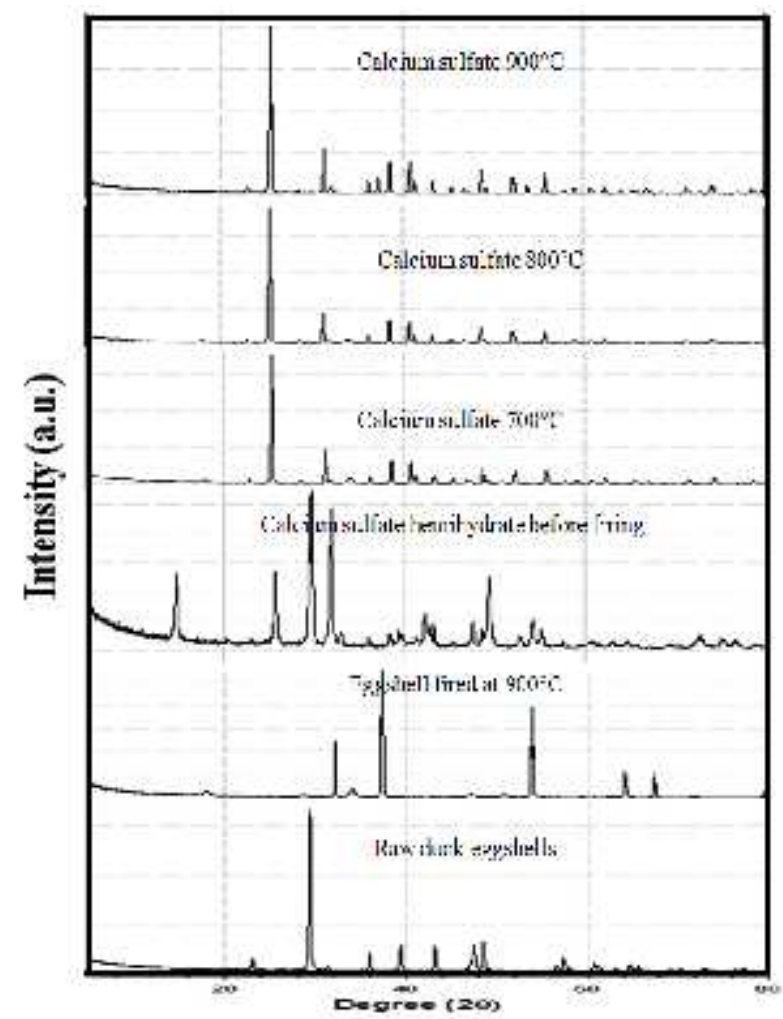

Fig.1 XRD peak patterns of the duck eggshell before and after calcination at $900^{\circ} \mathrm{C}$ for $2 \mathrm{hr}$ and calcium sulfate hemihydrate powder calcined at $700^{\circ}, 800^{\circ}$, and $900^{\circ} \mathrm{C}$, for $2 \mathrm{hr}$, respectively.

The SEM micrographs of duck eggshell powder, calcium sulfate hemihydrate powder before firing, and dried precipitated calcium sulfate hemihydrate powder calcined at $700^{\circ}, 800^{\circ}$, and $900^{\circ} \mathrm{C}$ with the magnifications of 1000 and 5000 times as shown in Fig. 2. The SEM micrographs of the ground raw duck eggshell powder show the particulate agglomeration and non-uniform size as shown in Figures 2a) and 2a-1). The SEM micrographs of the precipitated calcium sulfate hemihydrate powder, dried at $110^{\circ} \mathrm{C}$ without firing, show uniform needle shape crystal structure consistent with the results obtained by Freyer, D et al. [4], Licong, D. et al. [13], and Azimi G. et al. [32]. The SEM microstructures show starting the agglomeration of the needle shape to form plateor disk-like shape due to phase transformation at the firing temperature $700^{\circ} \mathrm{C}$ as shown in Figures 2c) and 2c-1) consistent with the SEM result obtained by Gartner, E.M. [33], and then the microstructures changed to more plate-like of the needle shape or crystallized as a metastable phase at firing temperature $800^{\circ} \mathrm{C}$ as shown in Figure 2d) and 2d-1). Furthermore, the microstructures changed and crystallized completely to form the small rod-like in shape that belong to stable anhydrite at calcination temperature $900^{\circ} \mathrm{C}$ as shown in Figures 2e) and 2e-1) consistent with the SEM results obtained by Azimi G. et al. [32]. 


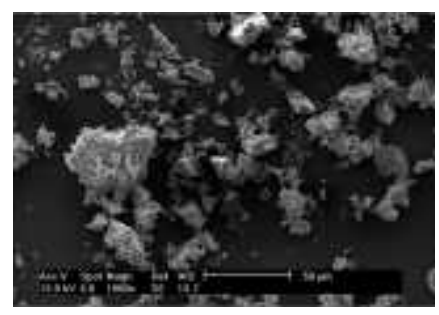

a)

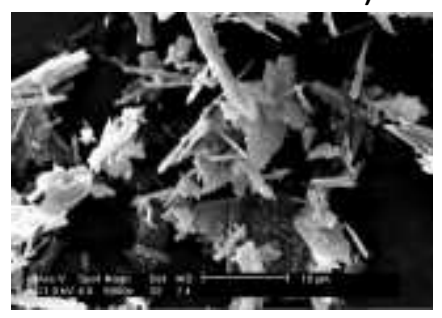

b-1)

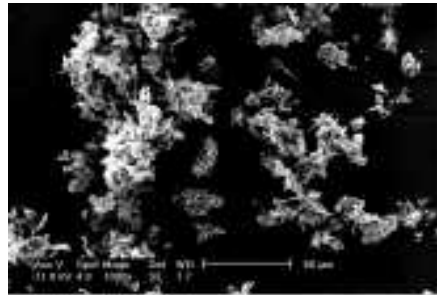

d)

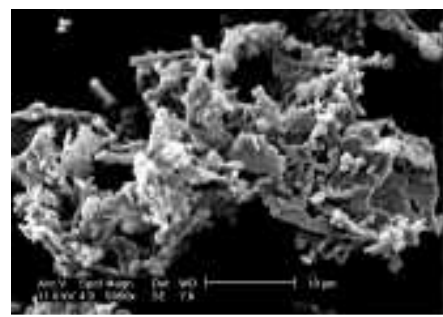

e-1)

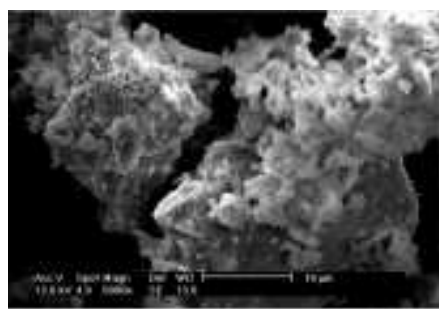

a-1)

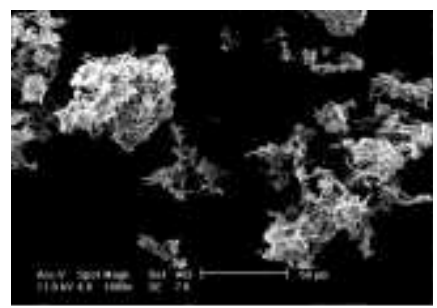

C)

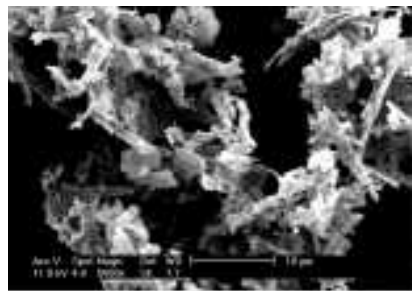

d-1)

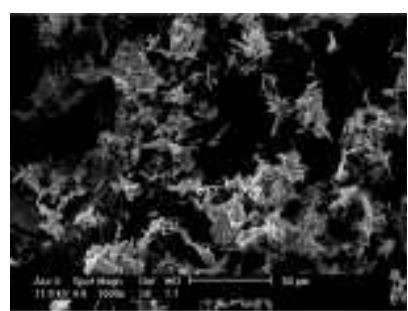

b)

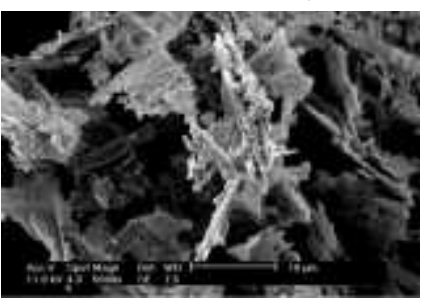

c-1)

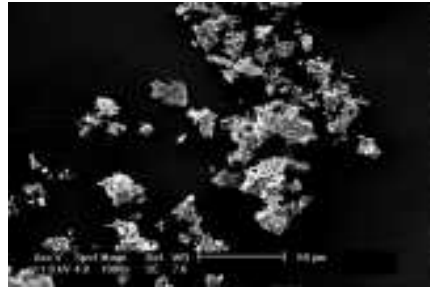

e)

Fig. 2 SEM micrographs of samples at magnifications of 1,000 and 5,000 times: a) and a-1) duck eggshell powder; b) and b-1) calcium sulfate hemihydrate $\left(\mathrm{CaSO}_{4} .0 .5 \mathrm{H}_{2} \mathrm{O}\right)$ powder before firing; $\left.\mathrm{c}\right)$ and c-1) calcium sulfate hemihydrate powder calcined at $\left.700^{\circ} \mathrm{C} ; \mathrm{d}\right)$ and d-1) calcium sulfate hemihydrate powder calcined at $800^{\circ} \mathrm{C}$; and e) and e-1) calcium sulfate hemihydrate powder calcined at $900^{\circ} \mathrm{C}$.

\section{Summary}

Duck eggshell is a potential material for use as the calcium carbonate $\left(\mathrm{CaCO}_{3}\right)$ source to react with sulfuric acid in order to prepare the calcium sulfate dihydrate or gypsum $\left(\mathrm{CaSO}_{4} \cdot 2 \mathrm{H}_{2} \mathrm{O}\right)$, calcium sulfate hemihydrate or plaster of Paris $\left(\mathrm{CaSO}_{4} \cdot 0.5 \mathrm{H}_{2} \mathrm{O}\right)$, and stable anhydrite $\left(\mathrm{CaSO}_{4}\right)$ in terms of $\mathrm{CaSO}_{4} \cdot \mathrm{xH}_{2} \mathrm{O}(\mathrm{x}=0.0-2.0)$ by thermal process. Calcium sulfate can form hydration and dehydration process due to water adsorption-desorption ability within the layered microstructure. Calcium sulfates have a potential candidate function as a binder, filler, absorbent, catalyst, and coagulant in a variety of buildings, ceramics, petroleum and petrochemical, dental and mechanical industries. Calcium sulfate dihydrate or gypsum is one of the important materials suitable for building, mold making, etc., whereas anhydrite or anhydrous calcium sulfate is suitable for function as a filler in various industries such as the paint, plastic, rubber, coating, cement, etc. [34-36]. There are many advantages of the chemical precipitation method used in this study for calcium sulfate compounds preparation i.e., easy and convenient forming, low price, and high purity calcium sulfate including waste eggshell reduction.
The obtained calcium sulfate dihydrate or gypsum can form at room temperature. When the calcium sulfate dihydrate $\left(\mathrm{CaSO}_{4} \cdot 2 \mathrm{H}_{2} \mathrm{O}\right)$ is dried at $110^{\circ} \mathrm{C}$, they can change to calcium sulfate hemihydrate or plaster of Paris $\left(\mathrm{CaSO}_{4} \cdot 0.5 \mathrm{H}_{2} \mathrm{O}\right)$ and transform to anhydrite or anhydrous calcium sulfate $\left(\mathrm{CaSO}_{4}\right)$ in terms of type III, type II, and type I at a temperature from $300^{\circ} \mathrm{C}$ to $1000^{\circ} \mathrm{C}$. The $\mathrm{XRD}$ phase formation of calcium sulfates will change from rhombohedral (gypsum) to hexagonal (anhydrite) crystal structure. The SEM micrograph will change from needle-like shape (hemihydrate or plaster of Paris) to plate- or disk-like shape, and to rod-like shape (anhydrite). The true density, color, odor, specific surface area, average pore diameter, and average particle size of the best anhydrite or anhydrous calcium sulfate obtained in this study calcined at $900^{\circ} \mathrm{C}$ are equal to $2.95 \mathrm{~g} / \mathrm{cm}^{3}$, white powder, odorless, $3.57 \mathrm{~m}^{2} / \mathrm{g}, 96.98 \AA$, and $3.983 \mu \mathrm{m}$, respectively.

\section{Acknowledgements}

The authors sincerely thank the Petroleum and Petrochemical College, and the Scientific and Technological Research Equipment Center, at Chulalongkorn University, Thailand; the Department of Materials Engineering, at Kasetsart 
University for the use of analytical instruments. We also have to thank the Energy and Environmental Engineering Center, Faculty of Engineering, Kasetsart University for eggshell separation. This work is grant supported by the Agricultural Research Development Agency (Public Organization) or ARDA of Ministry of Agriculture and Cooperatives, the Thailand Research Fund encoded PRP5605010080. In addition, we also would like to acknowledge the financial supports from the Conductive and Electroactive Polymers Research Unit of Chulalongkorn University, the Thailand Research Fund (TRF), and the Royal Thai Government.

\section{References}

1. Greish, Y.E., Phase evolution during the low temperature formation of stoichiometric hydroxyapatitegypsum composites, Ceram. Int., 37 (2011) 715-723.

2. Orsini, G., Rieei, J., Scarano, A., Pecora, G., Lezzi, G., and Biomed, J., Bone-defect healing with calciumsulfate particles and cement: an experimental study in rabbit, Mater. Res. B: Appl. Biomater., 68/2B (2004) 199-208.

3. Zhao, W., Yang, H., and Huo, C., Surface nano crystallization modification of anhydrite, Colloids Surf. A: Physicochem. Eng. Aspects., 393 (2012) 128-132.

4. Freyer, D., and Voigt, W., Crystaalization and Phase Stability of $\mathrm{CaSO}_{4}$ and $\mathrm{CaSO}_{4}$-Based Salts, Monatshefte für Chemie., 134 (2003) 693-719.

5. Reisdorf, K. and Abriel, W., System $\mathrm{CaSO}_{4}-\mathrm{H}_{2} \mathrm{O}$ über die Na-Polyhalit $\mathrm{Na}_{2} \mathrm{Ca}_{5}\left(\mathrm{SO}_{4}\right)_{6}\left(\mathrm{H}_{2} \mathrm{O}\right)_{3}$, Neues Jb. Miner. Abh., 157 (1987) 35-46.

6. Çetin, E., Eroğlu, ., and Özkar, S., Kinetics of gypsum formation and growth during the dissolution of colemanite in sulfuric acid, J. Cryst. Growth., 231 (2001) 559-567.

7. Hand, R.J., Calcium Sulphate hydrates: a review, British Ceramic Trans., 96 (1997) 116-120.

8. Deer, W.A., Howie, R.A., and Zussman J. in: An Introduction to the rock-forming mineral, $2^{\text {nd }}$ ed., Longman, London, 1992, pp. 627.

9. Packter, A., The precipitation of calcium sulphate dihydrate from aqueous solution. Induction periods, crystal numbers and final size, J. Cryst. Growth., 21/2 (1974) 191-194.

10. Klepetsanis, P.G., Dalas, E., and Koutsoukos, P.G., Role of temperature in the spontaneous precipitation of calcium sulfate dihydrate, Langmuir., 15/4 (1999) 15341540 .

11. Boisvert, J.P., Domenech, M., Foissy, A., Persello, J., and Mutin, J.C., Hydration of calcium sulfate hemihydrate $\left(\mathrm{CaSO}_{4}\right.$ center dot $\left.1 / 2 \mathrm{H}_{2} \mathrm{O}\right)$ into gypsum $\left(\mathrm{CaSO}_{4}\right.$ center dot $\left.2 \mathrm{H}_{2} \mathrm{O}\right)$. The influence of the sodium poly (acrylate)/surface interaction and molecular weight, J. Cryst. Growth., 220/4 (2000) 579- 591.

12. Kontrec, J., Kralj, D., and Brečević, L., Trans formation of anhydrous calcium sulphate into calcium sulphate dehydrate in aqueous solutions, J. Cryst. Growth., 240 (2002) 203-211.

13.Licong, D., Yifei, Z., Fangfang, C., Shaotao, C., Shaowei, Y., Yan, L., and Yi, Z., Reactive Crystallization of Calcium Sulfate Dihydrate from Acidic Wastewater and Lime, J. Chem. Eng., 21/11 (2013) 1303-1312.
14. Baltpurvins, K.A., Burns, R.C., Lawrance, G.A., Heavy metals in wastewater: modeling the hydroxide precipitation of copper II from wastewater using lime as the precipitant, Waste Manage., 16/8 (1996) 717-725.

15.Baltpurvins, K.A., Burns, R.C., Lawrance, G.A., Stuart, A.D., Effect of electrolyte composition on zinc hydroxide precipitation by lime, Water. Res., 31/5 (1997) 973-980.

16.Dabrowski, A., Hubicki, Z., Podkoscielny, P., and Robens, E., Selective removal of the heavy metal ions from waters and industrial wastewaters by ion-exchange method, Chemosphere., 56/2 (2004) 91-106.

17. Wingenfelder, U., Hasnsen, C., Furrer, G., Schulin, R., Removal of heavy metals from mine water by natural zeolites, Environ. Sci. Technol., 39/12 (2005) 46064613.

18.Dipalma, L., Ferrantelli, P., Merli, C., Petrucci, E., Treatment of the solution extracted from metal contaminated soils by reverse osmosis and chemical precipitation, Ann. Chim. (Rome)., 93/12 (2003) 10051011.

19.Lai, C.L., and Lin, K.S., Sludge conditioning characteristics of copper chemical mechanical polishing wastewaters treated by electrocoagulation, J. Hazard. Mater., 136/2 (2006) 183-187.

20.Böke, H., Akkurt, S., Özdemir, S., Göktürk, H., and Caner Saltik, E.N., Quantification of $\mathrm{CaCO}_{3}$ $\mathrm{CaSO}_{3} \cdot 0.5 \mathrm{H}_{2} \mathrm{O}-\mathrm{CaSO}_{4} \cdot 2 \mathrm{H}_{2} \mathrm{O}$ mixtures by FTIR analysis and its ANN model, Mater. Lett., 58 (2004) 723-726.

21.Kong, B., Yu, J., Savino, K., Zhu, Y., and Guan, B., Synthesis of -calcium sulfate hemihydrate submicronrods in water/n-hexanol/CTAB reverse microemulsion, Colloids Surf. A: Physicochem. Eng. Aspects., 409 (2012) 88-93.

22.Tsai, W.T., Yang, J.M., Lai, C.W., Cheng, Y.H., Lin, C.C., and Yeh, C.W., Characterization and adsorption properties of eggshells and eggshell membrane, Bioresour. Technol., 97 (2006) 488-491.

23. Nys, Y., Gautron, J., Garcia-Ruiz, J.M., Hincke, M.T., Avian eggshell mineralization: biochemical and functional characterization of matrix proteins, $C$. $R$. Palevol., 3 (2004) 549-562.

24. Murakami, F.S. and Rodrigues, P.O., Physico- chemical study of $\mathrm{CaCO}_{3}$ from egg shells, Ciénc. Technol. Aliment., Campinas, 27/3 (2007) 658-662.

25. Tangboriboon, N., Kunaruraksapong, R., and Sirivat, A., Meso-porosity and phase transformation of bird eggshells via pyrolysis, J. Ceram. Process. Res., 13/4 (2012) 413-419.

26. Tangboriboon, N., Khongnakhon, T., Kittikul, S. Kunanuraksapong, R., and Sirivat, A., An innovative $\mathrm{CaSiO}_{3}$ dielectric material from eggshells by sol-gel process, J. Sol-Gel Sci. Technol., 58/1 (2011) 33-41.

27. Tangboriboon, N., Phudkrachang, P., Kunanuruksapong, R., and Sirivat, A., removing extractable proteins in natural rubber latex by calcium chloride from chicken eggshells, rubber chem. Technol., 84/4 (2011) 543564.

28. Manual of Gas Sorption System," QUANTACHROME INSTRUMENTS, Auto sorb-1, Quantachrome Coorporation, Version 1.19. 
29. Ferreira, J.M.F., Role of the Clogging Effect in the Slip Casting Process, J Eur. Ceram. Soc., 18 (1998) 11611169.

30.Guan, B., Ye, O., Wu, Z., Lou, W., and Yang, L., Analysis of the relationship between particle size distribution of $\alpha$-calcium sulfate hemihydrate and compressive strength of set plaster-Using grey model, Powder Technol., 200 (2010) 136-143.

31. Singh, N.B., and Middendorf, B., Calcium sulphate hemihydrate hydration leading to gypsum crystallization, Prog. Cryst. Growth Charact. Mater., 53 (2007) 57-77.

32. Azimi, G. and Papangelakis, V.G., Mechanism and kinetics of gypsum-anhydrite transfor mation in aqueous electrolyte solutions, Hydrometallurgy., 108 (2011) 122129.
33.Gartner, E.M., Cohesion and expansion in polycrystalline solids formed by hydration reactions The case of gypsum plasters, Cem. Concr. Res., 39 (2009) 289-295.

34.Singh, M. and Garg, M., Making of anhydrite cement from waste gypsum, Cem. Concr. Res., 30 (2000) 571577.

35. Muraiu, M., Ferreira, A.D.S., Duquesne, E., Bonnaud, L., and Dubois, P., Polylactide (PLA) and highly filled PLA-calcium sulfate composites with improved impact properties, Macromol.Symp., 272 (2008) 1-12.

36. Gardette, M., Thérias, S., Gardette, J.I., Muraiu, M., and Dubois, P., Photooxidation of polylactide/calcium sulfate composites, Polym. Degrad. Stab., 96 (2011) 616-623.

\section{How to cite this article:}

Wanitcha Unjan and Nuchnapa Tangboriboon (2017) 'Bio-Calcium Sulfate Preparation From Duck Eggshell Via Chemical Reaction Process', International Journal of Current Advanced Research, 06(03), pp. 2454-2459. 